\title{
PEMBUATAN KARBOHIDRAZIDA DARI HIDRAZIN DAN ASAM SIANURAT
}

\author{
I Dewa Gede Arsa Putrawan*, Alfandra Ihsan, dan Sofyan \\ Kelompok Keahlian Perancangan dan Pengembangan Produk Teknik Kimia \\ Fakultas Teknologi Industri, Institut Teknologi Bandung \\ Jalan Ganesha 10 Bandung 40132 \\ Email: idewa@che.itb.ac.id
}

\begin{abstract}
Abstrak
Hidrazin umumnya digunakan sebagai pengikat oksigen dalam pengolahan air umpan boiler. Akan tetapi, senyawa ini merupakan bahan kimia yang mudah terbakar dan bersifat karsinogenik. Industri-industri di negara maju sudah lama mengkaji alternatif pengganti hidrazin sebagai pengikat oksigen dan sudah mulai meninggalkan hidrazin. Senyawa yang diperkirakan potensial untuk menggantikan hidrazin adalah karbohidrazida. Tujuan penelitian ini adalah untuk memahami rute sintesis karbohidrazida dan menentukan rute yang tepat serta menyusun langkah-langkah detil proses pembuatan karbohidrazida untuk penerapan lokal di tanah air. Studi literatur menunjukkan bahwa karbohidrazida dapat diperoleh dengan mereaksikan hidrazin hidrat dan asam sianurat, fosgen, dimetil karbonat atau difenil karbonat. Alur yang diperkirakan tepat untuk dikembangkan di Indonesia adalah alur melalui asam sianurat. Melalui uji coba di laboratorium, prosedur pembuatan karbohidrazida dari hidrazin dan asam sianurat yang detil telah disusun. Pada kondisi yang dikaji, karbohidrazida dengan kemurnian $90-92 \%$ dapat disintesis dengan perolehan pada rentang $20-60 \%$.
\end{abstract}

Kata kunci: karbohidrazida, asam sianurat, hidrazin.

\begin{abstract}
Hydrazine is commonly used as an oxygen scavenger in boiler feed water treatment. However, this compound is very flammable and is a carcinogenic substance. The industries in developed countries has studied the alternatives for hydrazine since long time ago and started to replace hydrazine. Carbohydrazide is known to be a good alternative for hydrazine. This research is aimed to understand the synthesis routes of carbohydrazide and to determine the best route as well as to develope a detail procedure of carbohydrazide preparation for local application. Literature study showed that carbohydrazide can be made by reacting hydrazine and cyanuric acid, phosgene, dimethyl carbonate or diphenyl carbonate. The synthesis path which is appropriate to be applied in Indonesia is that via cyanuric acid. From laboratory testing, a detail procedure for making carbohydrazide from hydrazine and cyanuric acid has been developed. In the range of experimental conditions studied, carbohydrazide with purity of $90-92 \%$ could be obtained with yield of $20-60 \%$.
\end{abstract}

Keywords: Carbohydrazide, cyanuric acid, hydrazine 


\section{Pendahuluan}

Boiler merupakan salah satu unit pendukung yang penting dalam industri proses. Boiler berfungsi untuk menyediakan kebutuhan panas di pabrik dengan mengubah air menjadi steam. Air yang dipasok ke boiler disebut air umpan boiler (boiler feed water). Air umpan boiler harus memenuhi persyaratan tertentu untuk menghindari kerusakan boiler. Penggunaan air umpan boiler yang tidak memenuhi persyaratan akan menimbulkan beberapa masalah, seperti korosi, pengerakan, dan busa. Salah satu penyebab terjadinya korosi pada boiler adalah oksigen dalam air umpan boiler. Oleh karena itu, oksigen harus disingkirkan sebelum air diumpankan ke dalam boiler. Menurut ASME Research Commitee on Steam \& Water in Thermal Power Systems, kadar oksigen dalam air umpan boiler untuk boiler tekanan rendah disarankan kurang dari 40 ppb sedangkan untuk boiler tekanan tinggi disarankan kurang dari 7 ppb (trace) (Nalco, 1978).

Penyingkiran oksigen dari air umpan boiler dapat dilakukan secara fisik dan kimia. Penyingkiran oksigen secara fisik dilakukan dengan cara deaerasi. Akan tetapi kadar oksigen terlarut dalam air keluaran deaerator dibatasi oleh kelarutan oksigen. Untuk mencapai kadar oksigen yang sangat rendah (kurang dari 7 ppb/trace) penyingkiran oksigen harus melibatkan bahan kimia. Bahan kimia yang digunakan untuk menyingkirkan oksigen terlarut dalam air disebut pengikat oksigen (oxygen scavenger).

Pengikat oksigen yang umum digunakan adalah natrium sulfit dan hidrazin. Natrium sulfit mampu bereaksi dengan oksigen terlarut dengan sangat cepat. Akan tetapi, reaksi yang terjadi menghasilkan senyawa sulfat yang mengkristal pada temperatur tinggi. Oleh karena itu, natrium sulfit tidak dapat digunakan pada boiler tekanan tinggi. Untuk boiler tekanan tinggi, hidrazin merupakan pengikat oksigen yang sangat populer. Disamping kemampuan mengikat oksigen yang dimiliki sangat tinggi, hidrazin menghasilkan produk yang tidak menimbulkan masalah pada temperatur tinggi. Tambahan pula, hidrazin sangat larut dalam air. Hidrazin saat ini mengisi pasar pengikat oksigen dalam jumlah yang paling besar.

Terlepas dari keunggulan-keunggulan yang disampaikan di atas, telah diketahui secara luas bahwa hidrazin merupakan bahan kimia yang sangat beracun, mudah terbakar dan membahayakan kesehatan. EPA (Environmental Protection Agency) menyatakan bahwa hidrazin merupakan bahan yang karsinogenik terhadap tubuh manusia. Industri-industri di negara maju sudah lama mengkaji alternatif pengganti hidrazin sebagai pengikat oksigen dan saat ini sudah mulai meninggalkan hidrazin. Dampak buruk hidrazin bagi kesehatan saat ini masih belum dipermasalahkan di tanah air sehingga hidrazin masih digunakan secara luas. Akan tetapi, mengingat dampak hidrazin merupakan permasalahan global, Indonesia juga perlu memikirkan alternatif pengganti hidrazin mulai dari sekarang. Senyawa yang diperkirakan potensial untuk menggantikan hidrazin adalah karbohidrazida (Slovinsky, 1981; Banweg, 2005).

Tujuan penelitian ini adalah untuk memahami alur sintesis karbohidrazida dan menentukan alur yang tepat untuk dikembangkan di Indonesia serta menyusun langkah-langkah detil tentang proses pembuatan karbohidrazida. Penelitian ini juga ditujukan untuk mempelajari pengaruh waktu reaksi dan perbandingan mol reaktan terhadap perolehan dan kemurnian karbohidrazida. Secara garis besar, penelitian ini terdiri dari tiga tahap yaitu studi literatur, pemilihan alur sintesis dan pengujian skala laboratorium.

\section{Dasar Teori \\ Pengolahan Air Umpan Boiler}

Boiler merupakan bagian dari sistim boiler yang menerima semua bahan pencemar dalam air seperti logam mineral dan gas-gas terlarut. Kinerja, efisiensi, dan umur layanan boiler merupakan hasil langsung dari pemilihan dan pengendalian air umpan boiler. Sistem pengolahan air umpan boiler terdiri dari pengolahan eksternal dan internal. Pengolahan eksternal digunakan untuk membuang padatan tersuspensi, padatan telarut (terutama ion kalsium dan magnesium yang merupakan penyebab utama pembentukan kerak) dan gas-gas terlarut (oksigen dan karbon dioksida). Proses perlakuan eksternal yang umum dilakukan adalah ion-exchange dan deaerasi (Iwata, 1985). Ion-exchange berfungsi menyingkirkan logam mineral dan deaerasi untuk menyingkirkan gas-gas terlarut. 
Oksigen merupakan salah satu gas terlarut yang bersifat korosif. Dalam pengolahan internal, pengikatan oksigen terlarut dalam air dilakukan dengan penambahan bahan kimia. Hal ini perlu dilakukan mengingat kemampuan deaerasi sebagai pengolahan eksternal dibatasi oleh kelarutan oksigen dalam air. Walaupun kelarutan oksigen dalam air dapat diturunkan ke level ppb. Namun, pada level itupun masih belum diperbolehkan untuk boiler tekanan tinggi. Untuk boiler tekanan tinggi oksigen terlarut disarankan mencapai nilai 0 (trace). Level ini hanya bisa dicapai dengan penambahan bahan kimia dalam pengolahan internal.

\section{Pengikat Oksigen}

Bahan kimia yang ditambahkan untuk mengikat oksigen disebut pengikat oksigen (oxygen scavenger). Pengikat oksigen yang baik memiliki kemampuan menurunkan oksigen hingga kadar yang rendah dan stabil pada temperatur tinggi. Pengikat oksigen yang paling sering digunakan adalah natrium sulfit $\left(\mathrm{Na}_{2} \mathrm{SO}_{3}\right)$ dan hidrazin $\left(\mathrm{N}_{2} \mathrm{H}_{4}\right)$ (Iwata, 1985).

Natrium sulfit mampu bereaksi dengan oksigen dengan cepat. Reaksi antara natrium sulfit dengan oksigen adalah:

$2 \mathrm{Na}_{2} \mathrm{SO}_{3}+\mathrm{O}_{2} \rightarrow 2 \mathrm{Na}_{2} \mathrm{SO}_{4}$

Dari reaksi di atas, kebutuhan natrium sulfit untuk menyingkirkan satu ppm $\mathrm{O}_{2}$ adalah 7,9 ppm. Kelemahan natrium sulfit terletak pada produk reaksi yang dihasilkan. Senyawa sulfat yang dihasilkan akan meningkatkan total padatan terlarut (TDS) dalam air umpan boiler. Pada tekanan tinggi, senyawasenyawa sulfat yang terlarut tersebut akan mengkristal membentuk kerak. Kerak akan menghambat perpindahan panas dan dapat juga menimbulkan erosi jika lepas dari dinding.

Hidrazin merupakan suatu senyawa kimia yang sangat reaktif terhadap oksigen serta larut dalam air dan alkohol (Kurzer dan Wilkinson, 1970). Reaksi antara hidrazin dengan oksigen adalah:

$\mathrm{N}_{2} \mathrm{H}_{4}+\mathrm{O}_{2} \rightarrow 2 \mathrm{H}_{2} \mathrm{O}+\mathrm{N}_{2}$

Hasil reaksi berupa gas nitrogen dan air sehingga total padatan terlarut (TDS) air tidak meningkat. Laju reaksi hidrazin dengan oksigen tidak secepat reaksi natrium sulfit dengan oksigen, tetapi dapat ditingkatkan dengan penambahan katalis. Berdasarkan reaksi di atas, kebutuhan hidrazin untuk menyingkirkan satu ppm $\mathrm{O}_{2}$ adalah satu ppm. Hidrazin memiliki sifatfisik yang mirip dengan air karena nilai densitas hidrazin sedikit di atas densitas air.

Walaupun sangat baik sebagai pengikat oksigen, hidrazin merupakan senyawa yang berbahaya bagi kesehatan. Hidrazin sangat beracun, dapat menyebabkan gangguan pernapasan dan bersifat karsinogenik. Bahan kimia yang dapat menggantikan peran hidrazin sebagai pengikat oksigen adalah hidroxylamine, erythorbic acid dan karbohidrazida. Di antara alternatif tersebut, karbohidrazida merupakan alternatif yang paling tepat karena memiliki kemampuan mengikat oksigen yang hampir sama dengan hidrazin dan juga aman bagi kesehatan maupun lingkungan.

\section{Karbohidrazida}

Karbohidrazida adalah senyawa turunan urea dengan rumus kimia $\mathrm{CO}\left(\mathrm{NHNH}_{2}\right)_{2}$ dengan berat molekul sebesar 90 (Kurzer dan Wilkinson, 1970; Othmer, 1993). Karbohidrazida berupa kristal putih dengan titik leleh $153{ }^{\circ} \mathrm{C}$. Karbohidrazida sangat larut dalam air. Persamaan reaksi yang terjadi antara karbohidrazida dengan oksigen adalah:

$\mathrm{CO}\left(\mathrm{NHNH}_{2}\right)_{2}+2 \mathrm{O}_{2} \rightarrow \mathrm{CO}_{2}+2 \mathrm{~N}_{2}+3 \mathrm{H}_{2} \mathrm{O}$

Dibandingkan dengan hidrazin, karbohidrazida lebih aman dari sisi kesehatan. Selain itu, karbohidrazida berbentuk padatan sehingga lebih mudah ditangani dibandingkan hidrazin yang berbentuk cairan. Tambahan pula, karbohidrazida telah mengalami uji coba selama sepuluh tahun di pembangkit listrik di Amerika dan terbukti handal (Banweg, 2005).

Berdasarkan kajian literatur, karbohidrazida dapat diproduksi dari beberapa metode sintesis, meliputi:

\section{Hidrazinolisis Ester Karbonat}

Menurut Curtius dan Kesting (Mohr dkk., 1953), karbohidrazida dapat dibuat dari hidrazin dan dialkil karbonat. Dialkil karbonat dapat berupa dimetil karbonat atau 
dietil karbonat $\left(\left(\mathrm{C}_{2} \mathrm{H}_{5} \mathrm{O}\right)_{2} \mathrm{CO}\right)$. Reaksi yang terjadi dengan menggunakan dietil karbonat adalah:

$\left(\mathrm{C}_{2} \mathrm{H}_{5} \mathrm{O}\right)_{2} \mathrm{CO}+2 \mathrm{~N}_{2} \mathrm{H}_{4} \cdot \mathrm{H}_{2} \mathrm{O} \rightarrow \mathrm{NH}_{2} \mathrm{NHCONHNH}_{2}$ $+2 \mathrm{C}_{2} \mathrm{H}_{5} \mathrm{OH}+2 \mathrm{H}_{2} \mathrm{O}$

Reaksi di atas berlangsung pada temperatur tinggi (95-120 ${ }^{\circ} \mathrm{C}$ untuk dietil karbonat dan 50-75 ${ }^{\circ} \mathrm{C}$ untuk dimetil karbonat) sehingga etanol/metanol yang terbentuk sebagai produk samping langsung menguap. Tanpa daur ulang reaktan perolehan karbohidrazida yang dicapai hanya $60 \%$. Perolehan karbohidrazida dapat ditingkatkan hingga mencapai 80\%. Dietil karbonat dapat digantikan dengan difenil karbonat. Perolehan yang dicapai tidak jauh berbeda. Dietil karbonat lebih disukai karena difenil karbonat menghasilkan produk samping (hidrazin fenat) yang sulit dipisahkan dari campuran hasil reaksi.

\section{Hidrazinolisis Fosgen}

Karbohidrazida dengan perolehan yang tinggi dapat dihasilkan dengan merefluks campuran hidrazin hidrat dan fosgen $\left(\mathrm{COCl}_{2}\right)$. Reaksi yang terlibat cukup kompleks. Pada tahap pertama hidrazin dan fosgen bereaksi menghasilkan hidrazin monohidroklorida $\left(\mathrm{NH}_{2} \mathrm{NHCOCl}\right)$ sebagai intermediet :

$\mathrm{N}_{2} \mathrm{H}_{4}+\mathrm{COCl}_{2} \rightarrow \mathrm{NH}_{2} \mathrm{NHCOCl}+\mathrm{HCl}$

Pada tahap kedua intermediet yang terbentuk dapat bereaksi dengan hidrazin maupun fosgen. Reaksi antara intermediet dengan hidrazin langsung menghasilkan karbohidrazida :

$\mathrm{NH}_{2} \mathrm{NHCOCl}+\mathrm{N}_{2} \mathrm{H}_{4} \rightarrow \mathrm{CO}\left(\mathrm{N}_{2} \mathrm{H}_{3}\right)_{2}+\mathrm{HCl}$

Reaksi intermediet dengan fosgen menghasilkan hidrazin dihidroklorida $\left((\mathrm{COClNH})_{2}\right)$ yang selanjutnya akan bereaksi dengan hidrazin menghasilkan hidrazidokarbohidrazida $\left(\left(\mathrm{CON}_{3} \mathrm{H}_{4}\right)_{2}\right)$ :

$$
\begin{gathered}
\mathrm{NH}_{2} \mathrm{NHCOCl}+\mathrm{COCl}_{2} \rightarrow(\mathrm{COClNH})_{2}+\mathrm{HCl} \\
(\mathrm{COClNH})_{2}+\mathrm{N}_{2} \mathrm{H}_{4} \rightarrow\left(\mathrm{CON}_{3} \mathrm{H}_{4}\right)_{2}+2 \mathrm{HCl}
\end{gathered}
$$

Tidak ada informasi detil tentang kondisi maupun selektivitas masing-masing produk. Dari literatur (Mohr dkk., 1953), diketahui bahwa perolehan karbohidrazida, hidrazin dihidroklorida, dan hidrazidokarbohidrazida akan merata jika reaksi berlangsung pada tekanan vakum.

\section{Hidrazinolisis Asam Karbazat} Asam karbazat $\left(\mathrm{NH}_{2} \mathrm{NHCOOH}\right)$ dapat diperoleh dengan menambahkan karbondioksida ke dalam larutan hidrazin. Reaksi yang terjadi adalah:

$\mathrm{N}_{2} \mathrm{H}_{4}+\mathrm{CO}_{2} \rightarrow \mathrm{NH}_{2} \mathrm{NHCOOH}$

Asam karbazat dengan hidrazin membentuk garam hidrazin :

$\mathrm{NH}_{2} \mathrm{NHCOOH}+\mathrm{N}_{2} \mathrm{H}_{4} \rightarrow \mathrm{NH}_{2} \mathrm{NHCOOH} . \mathrm{N}_{2} \mathrm{H}_{4}$

Garam yang terbentuk akan terurai menjadi karbohidrazida dan air jika dipanaskan hingga temperatur $140^{\circ} \mathrm{C}$. Reaksi penguraian yang terjadi adalah:

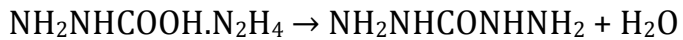

\section{Hidrazinolisis of Asam Sianurat}

Karbohidrazida dapat diperoleh dari reaksi antara hidrazin hidrat dan asam sianurat $\left((\mathrm{CONH})_{3}\right)$ (Argyle,1966). Reaksi dapat berlangsung pada temperatur rendah maupun tinggi, khususnya pada keadaan refluks sangat dianjurkan karena reaksi dapat berlangsung dengan laju reaksi yang besar. Reaksi yang terjadi adalah:

$(\mathrm{CONH})_{3}+6 \mathrm{~N}_{2} \mathrm{H}_{4} \rightarrow 3 \mathrm{CO}\left(\mathrm{NHNH}_{2}\right)_{2}+3 \mathrm{NH}_{3}$

Perolehan karbohidrazida bergantung pada konsentrasi dan jumlah hidrazin yang digunakan serta waktu reaksi. Konsentrasi hidrazin dianjurkan antara 25-50\%. Pada konsentrasi yang lebih rendah, waktu reaksi yang dibutuhkan menjadi lebih lama. Sedangkan pada konsentrasi yang lebih tinggi, terbentuk produk samping berupa 4aminourazole yang menyebabkan perolehan karbohidrazida berkurang. Dalam reaksi di atas hidrazin disarankan berlebih, minimum 10 mol untuk setiap $1 \mathrm{~mol}$ asam sianurat. Penggunaan hidrazin yang lebih sedikit mengakibatkan laju reaksi menjadi sangat rendah. Penggunaan hidrazin yang sangat berlebih sudah tentu sangat baik karena akan mempercepat reaksi, akan tetapi proses produksi menjadi tidak ekonomis. Hidrazin 
sebaiknya digunakan dalam jumlah yang minimal tetapi laju produksi masih dianggap wajar. Rasio mol hidrazin terhadap mol asam sianurat disarankan pada nilai 10-15 (Argyle, 1966). Air dan hidrazin sisa dapat disingkirkan melalui evaporasi untuk memperoleh karbohidrazida murni. Waktu reaksi bergantung pada konsentrasi dan jumlah hidrazin yang digunakan. Argyle memberikan satu contoh: dengan rasio mol 15 dan konsentrasi hidrazin $40 \%$ waktu yang dibutuhkan 18-20 jam, sedangkan pada penggunaan $10 \mathrm{~mol}$ dari $40 \%$ hidrazin memerlukan waktu 100 jam hingga keseluruhan reaksi selesai.

\section{Metodologi}

Bahan

Bahan-bahan utama yang digunakan dalam penelitian ini adalah hidrazin, asam sianurat, dan etanol. Hidrazin yang digunakan berupa larutan aquatik hidrazin hidrat $50 \%$. Sedangkan asam sianurat diperoleh dari hasil penelitian sebelumnya. Etanol yang digunakan berupa etanol azeotrop 95\% volum. Untuk keperluan analisis, bahan-bahan yang dilibatkan adalah larutan asam khlorida, khloroform, iodine, dan kalium iodate. Keempat bahan tersebut berupa bahan kimia kualitas analitik.

\section{Alat}

Peralatan yang digunakan dalam penelitian ini terdiri dari reaktor refluks, alat distilasi biasa, dan alat filtrasi, semua dalam skala laboratorium. Labu distilasi yang digunakan, baik untuk refluks maupun distilasi biasa, memiliki volume $2 \mathrm{~L}$.

\section{Prosedur}

Prosedur percobaan pada penelitian ini mengacu pada paten (Argyle, 1966). Blok diagram prosedur pembuatan karbohidrazida dapat dilihat pada Gambar 1. Percobaan diawali dengan mencampur larutan hidrazin dan asam sianurat sesuai dengan jumlah yang diinginkan.

Selanjutnya campuran direfluks selama waktu yang diinginkan. Setelah campuran selesai direfluks, 3/4volume hidrat diuapkan melalui distilasi biasa. Sisa distilasi selanjutnya didinginkan dan ditambahkan etanol sejumlah hidrat yang diuapkan, untuk mengendapkan karbohidrazida yang terbentuk. Endapan yang terbentuk kemudian disaring dan dicuci. Pencucian dan penyaringan dilakukan dengan menggunakan etanol sebanyak dua kali agar semua pengotor sisa dapat hilang. Produk yang terbentuk kemudian dikeringkan. Percobaan dilakukan pada rasio mol hidrazin terhadap asam sianurat sebesar 15 dan20, dengan waktu reaksi 10 dan 20 jam. Perolehan dinyatakan sebagai perbandingan berat produk yang terbentuk terhadap berat karbohidrazida stoikiometri. Kemurnian karbohidrazida dalam produk diukur melalui titrasi.

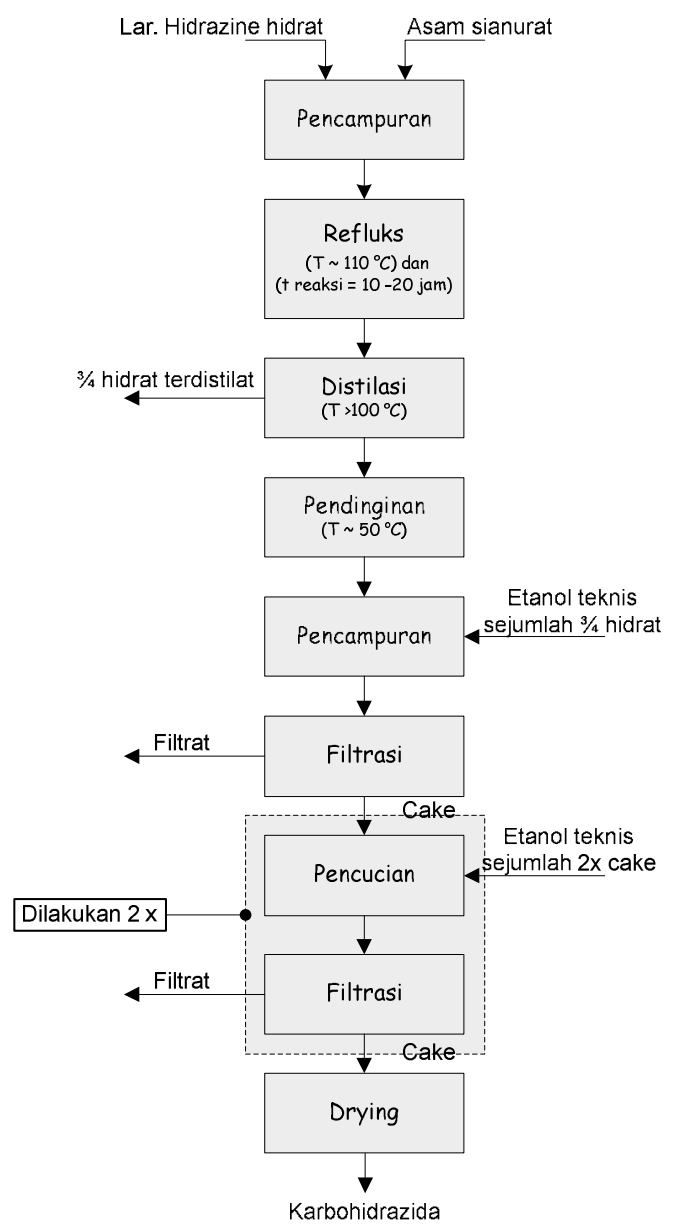

Gambar 1. Prosedur percobaan karbohidrazida

\section{Hasil dan Pembahasan Alur Sintesis Karbohidrazida}

Gambar 2 menampilkan alur sintesis karbohidrazida yang dibangun berdasarkan studi literatur. Semua metode sintesis menggunakan reaktan utama yang sama yaitu hidrazin. Perbedaannya terletak pada reaktan kedua yang digunakan. Reaktan kedua dapat berupa dialkil karbonat, fosgen, 
asam karbazat, atau asam sianurat. Alkil dalam dialkil karbonat dapat berupa metil, etil, maupun fenil. Bahan baku dari dialkil karbonat, fosgen, dan asam sianurat juga dapat dilihat pada Gambar 2. Ketiga dialkil karbonat pada dasarnya berasal dari fosgen. Fosgen merupakan senyawa yang sangat beracun.Asam karbazat juga merupakan senyawa yang sangat beracun. Sedangkan asam sianurat berasal dari urea yang tidak beracun dan urea juga merupakan bahan baku hidrazin serta tersedia di tanah air.

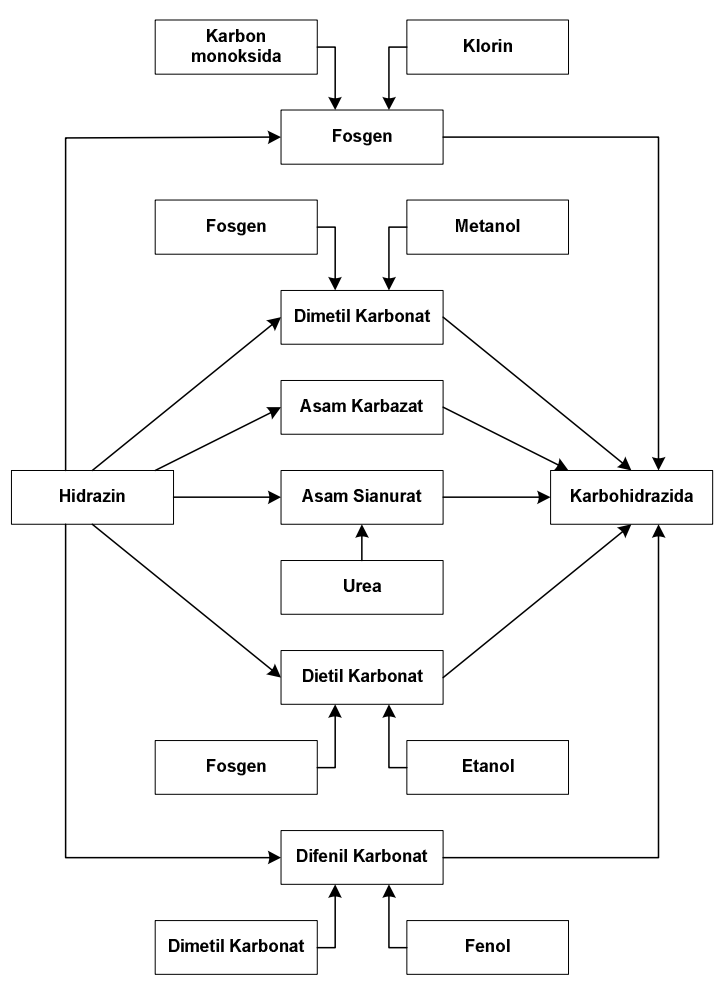
$\begin{array}{lrll}\text { Gambar } 2 . & \text { Rantai } & \text { penyusun } \\ \text { karbohidrazida }\end{array}$

Dari sisi kondisi operasi dan perolehan karbohidrazida, semua metode pada dasarnya sama. Semua reaksi dilangsungkan pada tekanan atmosferik dan temperatur didih campuran reaksi, dengan perolehan pada rentang 70-80\%. Dengan demikian pemilihan alur terbaik ditentukan oleh reaktan kedua yang digunakan. Alur asam karbazat dan dialkil karbonat (dimetil karbonat, dietil karbonat dan difenil karbonat) memerlukan fosgen sebagai bahan baku, sementara itu fosgen merupakan bahan beracun dan tidak tersedia di dalam negeri. Di lain pihak, alur asam sianurat memerlukan urea sebagai bahan baku dan urea tersedia dengan cukup di tanah air. Di samping itu, urea juga merupakan bahan baku hidrazin. Dengan kata lain, alur asam sianurat hanya memerlukan urea sebagai bahan baku. Mempertimbangkan ketersediaan bahan baku dari reaktan kedua, maka alur asam sianurat dipandang sebagai jalur yang paling aman dan tepat untuk dikembangkan di tanah air.

\section{Prosedur Pembuatan Karbohidrazida}

Seperti telah disampaikan di atas, metode pembuatan karbohidrazida yang tepat untuk dikembangkan di tanah air adalah metode melalui asam sianurat. Pembuatan karbohidrazida dari hidrazin dan asam sianurat dapat ditemukan dalam paten (Argyle, 1966). Dalam paten tersebut disampaikan bahwa karbohidrazida dapat diperoleh melalui: refluks asam sianurat dengan hidrazin berlebih (rasio mol hidrazin terhadap mol asam sianurat 15-20 selama 10 atau 20 jam), penyingkiran hidrazin sisa melalui distilasi biasa (3/4 volume hidrat teruapkan) dan kemudian pendinginan sisa distilasi untuk mengkristalkan karbohidrazida yang terbentuk (disertai penambahan alkohol). Prosedur yang ditampilkan dalam paten tersebut telah dicoba diterapkan dalam laboratorium. Setelah dicoba dilaksanakan diketahui ada beberapa hal penting yang tidak dijelaskan dalam paten tersebut.

Argyle(1966) menerangkan bahwa kristal karbohidrazida diperoleh melalui pendinginan dan penambahan alkohol tetapi tidak menerangkan secara detil apakah pendinginan atau penambahan alkohol yang dilakukan terlebih dahulu, dan juga tidak menyinggung senyawa alkohol yang digunakan maupun temperatur pendinginan. Penggunaan alkohol dapat dipastikan untuk mengurangi kelarutan karbohidrazida.Oleh karena itu, dalam penelitian ini digunakan alkohol yang termudah ditemukan, yakni etanol teknis. Mengingat karbohidrazida sangat larut dalam air, sementara etanol teknis mengandung air sekitar 5\% volume, pendinginan diusahakan pada temperatur dibawah suhu kamar. Dalam hal ini dipilih temperatur pendinginan $10^{\circ} \mathrm{C}$. Pendinginan dicoba melalui dua cara: setelah ditambah etanol dan sebelum ditambah etanol. Pendinginan sebelum penambahan etanol mengakibatkan sisa distilasi membentuk gel yang susah diaduk dan muncul warna ungu. Pendinginan setelah penambahan etanol menghasilkan kristal yang mudah dipisahkan 
dari larutan. Oleh karena itu, pendinginan disarankan setelah penambahan etanol. Dengan kata lain etanol ditambahkan langsung setelah hidrat sisa diuapkan.

Pada percobaan ini pencucian dilakukan dengan menambahkan alkohol (dua kali volume cake), diikuti dengan filtrasi.Pada mulanya etanol digunakan sebagai cairan pencuci. Cake hasil filtrasi menampakkan warna ungu, padahal sebelum dicuci cake benar-benar putih. Oleh karena itu, senyawa alkohol lain (metanol) dicoba juga sebagai cairan pencuci. Metanol juga dicoba, dengan merujuk paten Lange (1985). Ternyata metanol juga menampakkan cake warna ungu. Warna ungu tersebut ternyata hilang setelah kristal dikeringkan dalam oven. Sehubungan dengan hal tersebut, pencucian sebaiknya dilakukan dengan etanol. Etanol yang terbawa filtrat dapat diambil kembali menggunakan distilasi biasa, untuk digunakan kembali sebagai cairan pencuci maupun pembentukan kristal. Pencucian dilakukan sebanyak dua kali agar zat pengotor sisa dapat dihilangkan.

Berdasarkan pembahasan yang disampaikan di atas, telah disusun prosedur pembuatan karbohidrazida dari hidrazin dan asam sianurat yang lebih detil dari paten Argyle (1966). Diagram blok dari prosedur yang detil tersebut ditampilkan di Gambar 1 . Serangkaian percobaan kemudian dilakukan pada variasi waktu reaksi dan perbandingan mol hidrazin terhadap asam sianurat. Adapun hasil yang diperoleh ditampilkan dalam paragraf-paragraf berikut.

\section{Produk Karbohidrazida}

Uji coba menunjukkan perolehan karbohidrazida pada rasio mol hidrazin terhadap mol asam sianurat sebesar 15, adalah $20 \%$ pada waktu reaksi 10 jam dan $60 \%$ pada waktu reaksi 20 jam. Pada waktu reaksi 10 jam, kenaikan rasio mol hidrazin terhadap mol asam sianurat juga tetap tidak meningkatkan perolehan (nilai perolehan hanya $20 \%$ pada rasio mol 20). Hal ini menunjukkan bahwa reaksi berlangsung lambat sehingga waktu 10 jam memberikan perolehan yang rendah. Menurut Argyle (1966), perolehan karbohidrazida dengan mereaksikan asam sianurat dan hidrazin pada perbandingan mol reaktan 15 danwaktu reaksi selama 20 jam adalah sekitar 70\%. Uji coba menunjukkan bahwa perolehan pada kondisi yang sama adalah
60\%, 10\% lebih kecil dibandingkan dengan yang disampaikan Argyle (1966). Hal ini dipastikan karena ada bahan hilang selama pencucian. Walaupun ada sedikit perbedaan, tampak bahwa pengujian di laboratorium tidak jauh berbeda dengan yang disampaikan oleh Argyle (1966).

Analisis kemurnian karbohidrazida dilakukan melalui titrasi menggunakan kalium iodat $\left(\mathrm{KIO}_{3}\right)$, dengan metode dari Keim dkk. (1950). Kemurnian produk karbohidrazida yang dihasilkan dari setiap run cukup tinggi (90-92\%). Tidak ditemukan perbedaan kemurnian berarti dari semua produk karbohidrazida yang diperoleh. Produk karbohidrazida yang diperoleh berupa kristal berwarna putih. Mempertimbangkan warna, bentuk kristal, dan bau, produk yang diperoleh dapat dikatakan sama dengan produk karbohidrazida yang komersial.

\section{Kesimpulan}

Karbohidrazida dapat diperoleh dengan mereaksikan hidrazin hidrat dan asam sianurat, fosgen, dimetil karbonat atau difenil karbonat. Metode pembuatan karbohidrazida yang tepat dikembangkan di Indonesia adalah metode menurut Argyle (1966). Prosedur detil pembuatan karbohidrazida berdasarkan informasi yang diberikan oleh Argyle telah dikembangkan dan diuji di laboratorium. Uji coba menunjukkan bahwa kristal karbohidrazida dengan kemurnian 90-92\% dapat dihasilkan dengan perolehan pada rentang 20-60\%. Pada rasio mol hidrazin terhadap mol asam sianurat sebesar 20 jam untuk mencapai perolehan sebesar $60 \%$. Jika reaksi dilangsngkan kurang 20 jam, perolehan karbohidrazida sangat kecil walaupun menggunakan rasio mol yang lebih besar. Mengingat laju reaksi yang sangat lambat, perlu dikaji upaya peningkatan laju reaksi sehingga komersialisasi proses lebih mudah untuk diwujudkan.

\section{Ucapan Terima Kasih}

Terima kasih disampaikan pada ITB atas dukungan dana melalui Riset ITB 2010 dan PT. Zeus Kimiatama Indonesia atas pemberian hidrazin dan sampel karbohidrazida. 


\section{Daftar Pustaka}

Argyle, C. S., Process for the Preparation of Carbohydrazide, U.S. Patent 3,258,485, June 1966.

Banweg, A.; Wiltsey, D. G.; Nimry, B. N., Carbohydrazide-A Hydrazine Replacement:10 Years of Utility Experience, Institute of Power Engineers, 2005, 4-5.

Iwata, 0., Kurita Handbook of Water Treatment, Kurita Water Industries Ltd., 1985.

Keim, G. I.; Henry, R. A.; Smith, G. B. L., The Oxidation of Di- and Triaminoguadine with Potassium Iodate, U.S. Naval Ordnance Test Station, China Lake, California, 1950.

Kurzer, F.; Wilkinson, M., The Chemistry of Carbohydrazide and Thiocarbohydrazide, Chemical Reviews, 1970, Vol. 70(1), 111-149.
Lange Jr.,; P. H., Process for Making Carbohydrazide, U.S. Patent 4,496,761, 1985.

Mohr, E. B.; Brezinski, J. J.; Audrieth, L. F.; Ritchey, H. E.; McFarlin, R. F., Carbohydrazide, in Inorganic Synthesis, Bailar Jr., J. C. (Ed), 1953, Vol. 4, 32-35.

Nalco Chemical Company, Oxygen Scavenger, Bulletin of Nalco Chemical Company, 1978, Vol. 116.

Othmer, K., Encyclopedia of Chemical Technology Vol. 13, John Willey and Sons, New York, 1993, 560-566, 594-595.

Slovinsky, M., Boiler Additives for Oxygen Scavenging, U.S. Patent 4,269,717, May 1981. 